\title{
Grazing Management: An Art \& Science
}

\author{
On Western rangelands, grazing management \\ impacts the ecological sustainability of ranching.
}

\author{
By Dan Robinett with the USDA-NRCS in Tucson, Arizona
}

$\mathrm{R}$ anching is a widespread and important human use of rangelands that has occurred for over 200 years. It is the grazing of livestock (primarily cattle and horses) on native (and sometimes non-native) vegetation. Rangeland is land on which the historic potential plant community is predominantly grasses, grasslike plants, forbs or shrubs.

The ecological sustainability of ranching depends upon the safe harvest of renewable forage resources from rangelands. Sustainable ranching relies on grazing management to maintain plant and animal communities in satisfactory condition, to protect soils from accelerated erosion and to allow natural ecosystem processes to continue.

Livestock grazing is the consumption of rangeland plants by domestic herbivores. Rangeland herbage or forage is a renewable natural resource. It is produced yearly in the relatively simple interaction of sunlight and precipitation with rangeland plants and soils. Most rangeland plants, especially grasses, have evolved and adapted to tolerate grazing by some animal species. Research has shown that most forage (plant) species can tolerate the removal of some percentage of the yearly production of leaves, stems and or twigs without ill effects.

The various effects of grazing on plants have been documented. Grazing utilization of forage plants is expressed as the proportion of the current year production removed or damaged by grazing animals. It is expressed in percent. Proper use of rangeland forage resources is defined as "a degree of use of current year's growth which, if continued, will maintain or improve the range condition consistent with conservation of other natural resources. Proper use varies with time and systems of grazing."

The question then becomes what constitutes proper use, and many generalized proper use percentages have been placed in management documents as standards to be attained without defining how, when, where, and what is to be measured. There are many different ways to measure and determine grazing utilization. There are also many different ways to interpret and use utilization information.

\section{Determining Proper Use}

Grazing utilization is usually measured at key grazing areas and on key species within a pasture. A key grazing area is a relatively small portion of a pasture selected because of its location, use, or grazing value as a monitoring point for grazing use. A key species is a single plant species or group of similar species chosen to serve as a guide to the grazing use of the entire plant community.

If the key species on the key area is properly grazed, the entire plant community will not be excessively grazed. Moderate utilization of plant herbage allows plants to meet their physiological requirements. Moderate levels of use have been described as 30 to 50 percent (of yearly production) depending on the plant species and the nature of the rangeland.

Despite the complexities of determining precise proper use percentages, experience and research on semi-desert grasslands has provided some guidance. Martin and Cable concluded for a 10-year study of seasonal and yearlong grazing on the Santa Rita Experimental Range, in southern Arizona, that utilization substantially greater than 40 percent was consistently detrimental to perennial grasses on pastures grazed yearlong or seasonally. The 10-year average use during the study was 45 percent with the highest use of 70 percent in 1962 and the lowest use of 30 percent in 1966. This average allowed for range improvement.

It is important to recognize that Martin's and Cable's conclusions are based on average use of perennial grass-

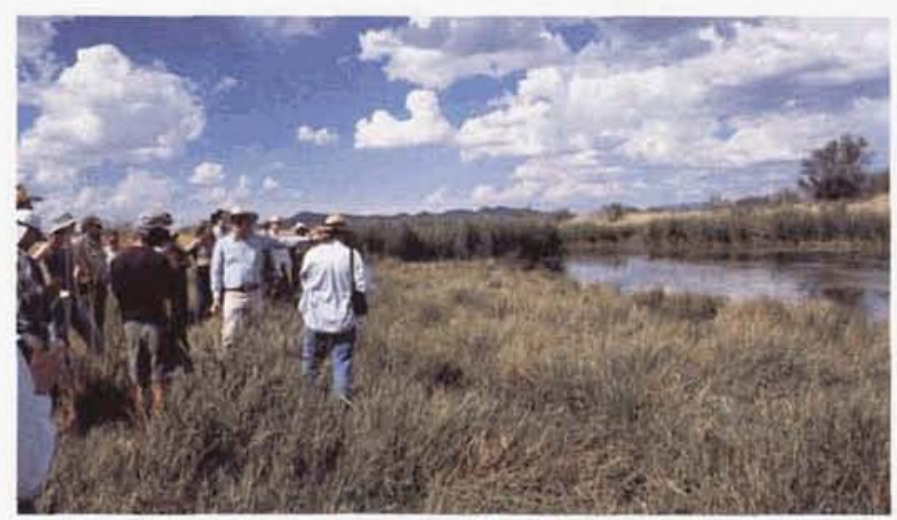

Empire Ranch Cienega Creek Bottom lands. Sustainabily grazed since 1975. 
es on permanent plots for all treatment pastures averaged over years. The wide range of annual utilization occurred even though livestock numbers were adjusted each fall based on the production of annual and perennial grasses during the previous summer. The determination of a proper stocking rate for a specific rangeland, to stay within the 10-year $45 \%$ utilization guideline depends on the rancher's ability to quickly adjust livestock numbers during drought.

Light to moderate grazing provides the margin of safety to deal with annual variability of the forage supply and provide for maintenance of the range forage resource. Light to moderate grazing is defined as 30 to 50 percent utilization of the yearly production of perennial grasses available to livestock on a range.

It should be pointed out that many experienced range managers (including ranchers) can tell when a pasture has been properly grazed by the appearance of the area. Properly grazed pastures tend to have a rough appearance. When 50 percent average utilization occurred on Arizona cottontop, a key species on some southern Arizona rangelands, nearly 40 percent of the plants remained ungrazed lending a patchy appearance to the pasture.

\section{Grazing Impacts Entire System}

Livestock grazing can have effects other than the direct impacts upon plants. Research has shown that some levels of grazing can alter rangeland hydrologic characteristics.

High livestock densities can cause compaction of surface soils increasing the ratio of runoff to rainfall. Less water infiltrates the soil and reduced soil moisture is available to maintain plant growth and cover. The entire hydrology of the system is negatively affected.

Low livestock densities have been found to have insignificant impacts on soil hydrology when compared to ungrazed areas. Livestock grazing can affect the diversity and composition of both plant and animal species on rangelands.

Continuous livestock grazing in wetlands and /or riparian areas can cause changes in stream channel morphology, increase erosion and affect reproduction of important tree and shrub species.

Other impacts of livestock grazing can change the way natural processes occur. Poor grazing practices can reduce the vigor of forage species making them less able to survive periodic drought and less able to compete with nearby, ungrazed plants. Improper grazing management can aid the spread of some non-native plant species and some noxious plant species by removing forage species, creating soil disturbance and opening the plant community to invasion. Improper grazing management can reduce plant cover and accelerate soil erosion above natural rates.

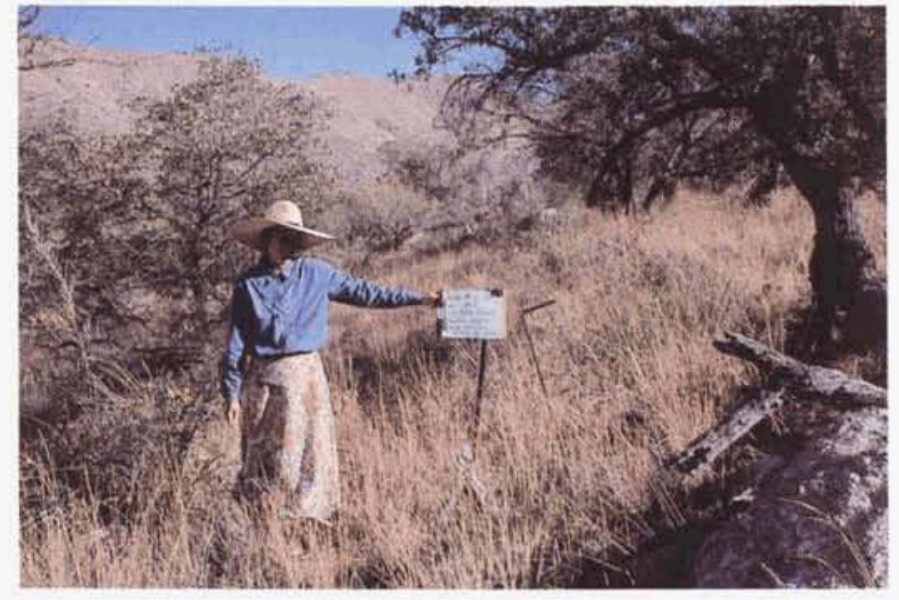

Anvil Ranch, Pima County, Arizona. Posito pasture.

\section{Management Begins With Inventory}

Effective and sustainable management of rangelands requires a basic inventory of the natural resources. Systems of rangeland classification have been developed and have been in use for over 50 years. The basis for these systems is soil survey.

Soils are mapped within moisture and temperature regimes according to taxonomy developed in the United States by the Soil Conservation Service (SCS) and used worldwide. A rangeland classification system developed by the Natural Resources Conservation Service (NRCS, formerly the SCS) is in use by most state and federal land management agencies in the region. In this system, similar soils, within climatic/geographic zones called Major Land Resource Areas are lumped together into units called ecological sites.

An ecological site is a distinctive kind of land with specific physical characteristics that differs from other kinds of land in its ability to produce a distinctive kind and amount of vegetation. Ecological sites are described with written narratives of the sites' physical characteristics, soils and natural vegetation. They are the recommended basic unit of rangeland classification.

The broad climatic/geographic zones, MLRAs and Ecoregions correspond to geographic provinces or ecosystems. Major Land Resource Area 40 is the Sonoran Desert, MLRA 30 is the Mojave Desert, MLRA 42 the Chihuahuan Desert, and so on. A potential native plant community is described for each ecological site including the percent composition of each species in the plant community. Total herbage production for the potential plant community (air-dry pounds per acre) is also shown for favorable, normal and unfavorable (rainfall) years.

An assessment of the status of rangeland is needed to provide a benchmark "condition" by which to measure the progress of range management. Ecological site descriptions show a historic, native, potential plant community. New theory for ecological sites and plant suc- 
cession called "State and Transition" allows for multiple, stable plant communities to be potential on a site. This model is presently being incorporated into ecological site descriptions.

The range assessment has become a triad of measurements. The first is called "Similarity Index" and is simply a numerical comparison of the present day plant community to the potential plant community. The second is called "Range Trend" and is the direction to or from the potential as measured by repeated measurements of vegetative characteristics over time. The third part of the assessment called Range Health, is a newly developed technique that attempts to describe site stability, watershed function and energy flow as compared to what should be normal for an ecological site. It is defined as the degree to which the integrity of the soil, vegetation, water, air and ecological processes of the rangeland ecosystem are balanced and sustained. Although qualitative, this procedure when done as described, can be combined with Range Trend and Similarity Index to form a reasonable basis of the current status of any piece of rangeland.

\section{Devising A Successful Grazing Plan}

Grazing management is key to ecological sustainability of ranching in this region. It is both an art and a science. It is defined as the manipulation of grazing animals to accomplish desired results. Managed grazing is successful when the needs of forage plants and soils are carefully balanced with the needs of livestock. The most important factor is to balance the number of animals on the land with the amount of forage that can be safely harvested by considering the timing, frequency, duration, season of use and the intensity of plant material removal.

Two terms common to range management are involved. They are Stocking Rate and Carrying Capacity. Carrying capacity is the average number of animals per area that the land can support while maintaining or improving the productivity of plants, soils and other components of the rangeland ecosystem. The average comes from the highs and lows needed for flexible stocking to accommodate the natural fluctuation in forage production from year to year.

The concept of carrying capacity is useful for administrative purposes (agencies) and as a guideline to use when stocking a range. It is best determined by a process of stocking animals on the range, managing grazing and monitoring vegetation over a long period to determine trend. When rangeland is stocked higher than its carrying capacity the number of animals and forage is out of balance.

Stocking rate is the number of animals utilizing a piece of rangeland for a specific period of time. In this region where production of perennial grasses can vary from 50 to 150 percent of average from year to year many authors recommend stocking be adjusted yearly to balance the numbers of animals with available forage.

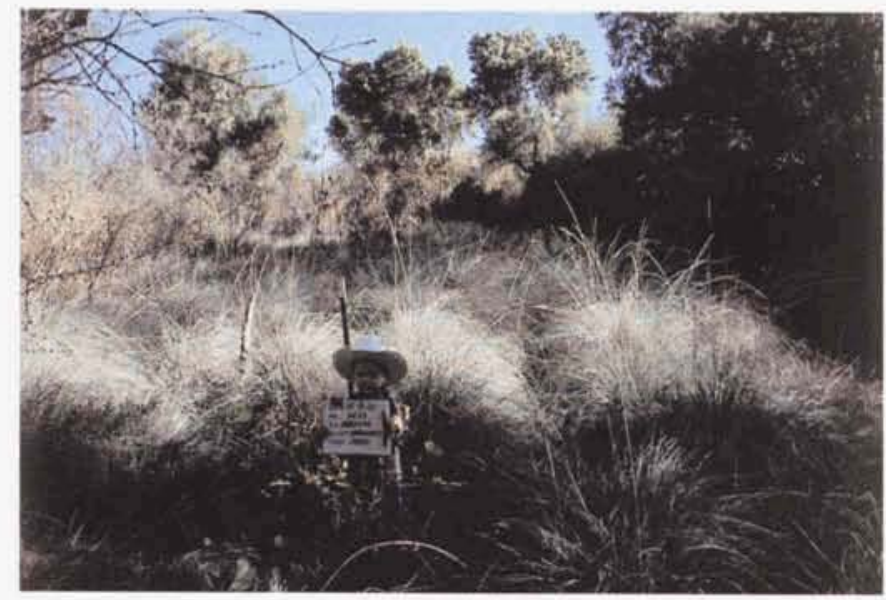

Babacomari Ranch. Rested river pasture since April Ist 2001.

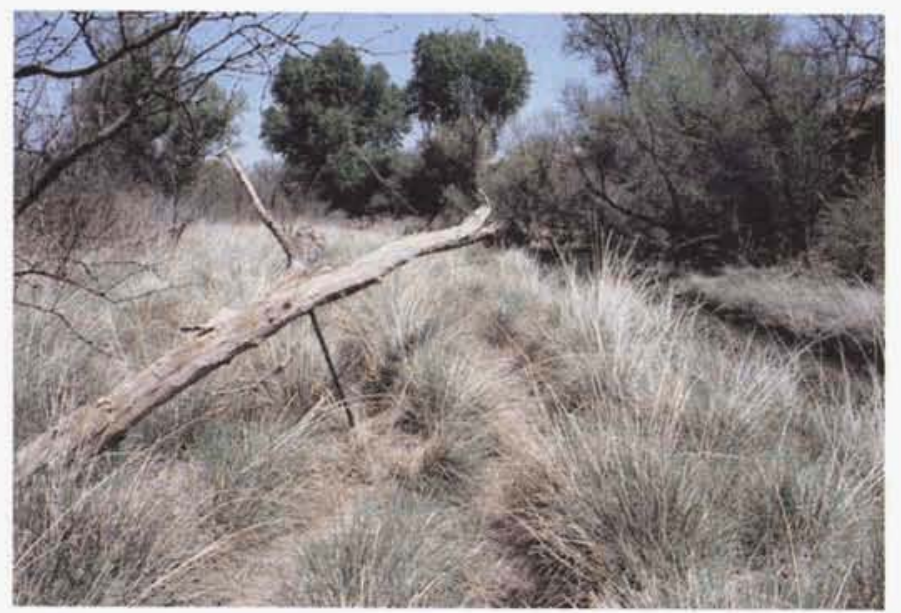

Babacomari Ranch. Proper use of river pasture. April 2000.

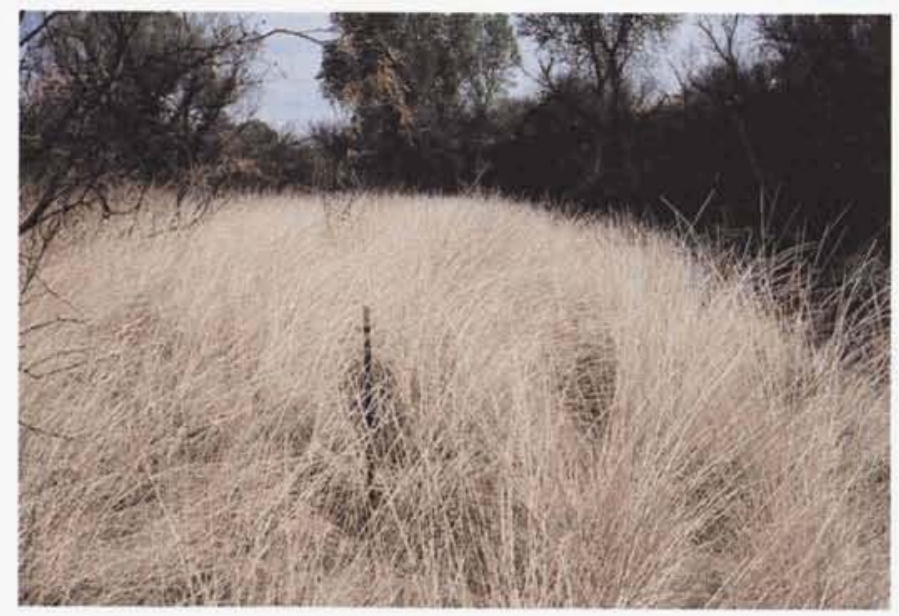

Babacomari Ranch. Rested 1998 -newly fenced river pasture. 
Another important factor in well managed grazing is the application of some system of grazing and then resting areas (pastures) from grazing, to allow for regrowth and reproduction of forage species. Research shows that the application of conservative stocking rates is the most important variable in sustainable grazing. Most grazing studies in this region show no difference between yearlong grazing and rotational grazing in overall range conditions when conservative rates of stocking are used.

However in most of Arizona's hot and rugged rangelands yearlong grazing at any level results in large "beat out" areas around (natural and man made) water locations, washes, canyon bottoms and ridge tops. Given the political climate of public land grazing today "sacrifice areas" are no longer acceptable and some type of rotational grazing system is needed to allow them to recover. Many grazing systems have been developed which work in this region.

An ideal grazing system would have a single herd of animals move into a pasture, harvest a crop of forage at a moderate level of utilization and then not come back to that pasture until a new crop of forage has been produced. The best grazing systems are evolved over 20 or 30 years to fit the needs of an individual ranch and rancher. Their level of sophistication increases over time as what works and does not work gets sorted out and as fences and water developments are added to achieve the needed flexibility. Grazing periods are generally short and rest periods long.

There are many examples of ranches in this region that have developed grazing systems that work and result in improvement in rangeland condition. The goal is grazing at an intensity that will maintain enough cover to protect the soil and maintain or improve vegetation. A moderate level of utilization is an average made up of individual levels of use on millions of plants. When a pasture is grazed some plants are used heavily and some lightly to not at all. This phenomenon varies considerably from plant species to species. Grazing systems are needed to compensate for the lack of uniformity in grazing utilization.

Sideoats grama plants clipped to a three-inch stubble ( $70 \%$ use) in late August had significantly less production than unclipped plants the following spring. But these same plants when rested the following spring and summer actually produced more than the unclipped plants. Rest periods are designed to be long enough to allow the heavily grazed plants to recover and forage species to produce seed, stolons or rhizomes and young plants to become established.

Well executed grazing systems result in a reserve of forage which can mediate the effects of drought on livestock carrying capacity and productivity. Well managed systems also maintain a high quality of livestock diet throughout the grazing year and provide for less variation in livestock production from dry to wet years.

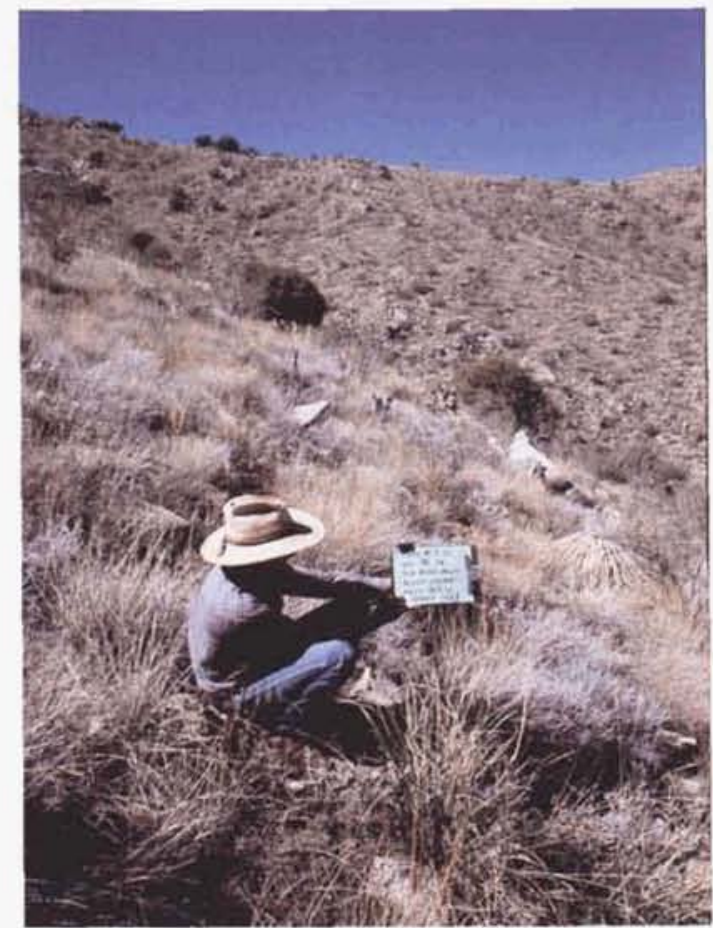

Elkhorn Ranch sustainably grazed since 1984. Horse pasture burned in 1987.

\section{Monitoring Is Essential}

The third important factor in well managed grazing is the application of some systematic process of planning, applying management, monitoring, feedback, replanning and repeating the process each grazing year. This provides a feedback loop allowing for continued refinement of grazing management.

This process begins in the fall of the year after the forage crop for the coming year is produced. A grazing plan is prepared for the coming year balancing the forage at hand and the numbers of animals. Information about range trend and condition from previous years' monitoring is used to refine the plan. Through the year animals are grazed and moved. Grazing utilization, season of grazing, numbers of animals and precipitation are recorded.

Grazing may be replanned in the spring to deal with climatic events. Stocking rate may be adjusted to account for spring forage production. In the early fall, after the peak standing crop of herbage is produced, vegetation is monitored by reading permanent transects located in strategic areas. Many techniques are available and in use.

The most commonly used methods include information such as frequency, density and cover of plant species. Vegetation monitoring measures the trend in the plant communities and can help determine progress toward meeting range condition and health objectives for the major ecological sites on a ranch.

Vegetation monitoring when combined with precipitation records and grazing utilization data can help deter- 
mine the causes of changes in plant species composition and cover. In the fall of the year the new forage crop is evaluated, monitoring results are considered and a new grazing plan prepared for the coming year.

The process repeats itself. The feedback loop of this process can also stimulate the need for additional rangeland research. It can identify where information is lacking to make good decisions in management application. Research needs can be taken to universities or the research arms of agencies for further study. Information about ecological sites from long-term vegetation and climate monitoring is important to expand our knowledge of sites and their variability, resilience and reaction to management.

\section{Records Imperative For The Future}

There are many ranches across this region on public, state and private rangelands that practice sustainable grazing. Excellent institutional examples of sustainable grazing include the Santa Rita Experimental Range managed by the University of Arizona near Tucson and the Jornada Experimental Range managed by Agricultural Research Service near Las Cruces. Conservative grazing on the Jornada Experimental Range was sustainable as documented by the 48 year range data set from 1941 to 1989. There are several characteristics common to the grazing management used on these ranches and experimental ranges. They tend to be conservatively stocked. They employ short grazing periods ( 1 to 3 months) and long rest periods ( 6 to 18 months). Stocking rates are flexible and monitoring is used to refine the system.

In the past some range conservationists and ranchers, working together, practiced sustainable livestock grazing without so much as sharpening a pencil. It was accomplished with constant attention to the interactions of livestock, vegetation, climate and management actions. A great deal of time was spent on the range, looking at the condition of the land and moving livestock. The range-

\section{Sustainable rangelands start with management}

The ecological sustainability of ranching depends upon the safe harvest of renewable forage resources from rangeland. It relies on grazing management to maintain plant and animal communities in satisfactory condition, to protect soils from accelerated erosion and to allow natural ecosystem processes to continue.

Effective rangeland management requires a basic understanding of plants, soils and animals and their reaction to grazing. It requires an understanding of the nature of the rangeland resources, ecological sites and their plant communities as well as concepts like range condition, trend, range health, stocking rate and carrying capacity. It employs management actions like grazing systems and proper use and tools like fencing, water development, brush management, grazing, animal impact, rest and fire to achieve sustainability.

And finally it uses a process of planning, management, monitoring and feedback to continually refine the activities unique to a particular ranch. land vegetation was given as much consideration as the livestock. The accumulated skills and judgment of one or two lifetimes resulted in good range conditions but left no record except the actual appearance of the land.

Today, where management decisions are made as often by the courts as they are by range managers, it is imperative that the process of range management be more inclusive, that monitoring be done and that judicious records be kept.

\section{References}

Andrade, I.F. de 1979, Growth response of sideoats grama to seasonal herbage removal and competition from adjacent vegetation. Ph.D. Dissertation. University of Arizona, Tucson, Arizona.

Blackburn, W.H., M.K. Wood and R.W.Knight. 1982. Impact of grazing on watersheds : A state of the knowledge. College Station, Texas. Texas A \& M University.

BLM National Applied Resource Science Center. 1996a. Utilization studies and residual measurements. Interagency Technical Reference 1734-3. Denver, Colorado.

Frost, W.E., E.L. Smith, and P.R. Ogden. 1994. Utilization guidelines. Rangelands. 16:256-259.

Holechek, J.L. 1991. Chihuahuan desert rangeland, livestock grazing and sustainability. Rangelands. 13(3) 115-120.

Jones, A. 2000. Effects of cattle grazing on North American arid ecosystems: A quantitative review. Western North American Naturalist. 60(2) 155-164.

Martin, S.C. and D.R. Cable. 1974. Managing semidesert grass shrub ranges: Vegetation responses to precipitation, grazing, soil texture and mesquite control. USDA Technical Bulletin 1480.

Martin, S.C. and C.R. Whitfield (editors). 1973. Grazing systems for Arizona ranges. Arizona Interagency Range Committee. Tucson, Arizona.

Natural Resources Conservation Service. 1997. Natural Range and Pasture Handbook. Grazing Lands Technology Institute.

Natural Resource Council. 1994. Range Health, new methods to classify, inventory and monitor rangelands. National Academy Press. Washington DC.

Pellant, M., P.L. Shaver, D.A. Pyke, and J.E. Herrick. 2000. Interpreting indicators of rangeland health, Version 3. USDANRCS and USDI- BLM Technical Reference 1734-6. National Science and Technology Center. Denver, Colorado.

Pieper, Rex D., Reldon Beck, Robert R. Gibbons, and Gary B. Donart. 1993. Sustainable Livestock Grazing in New Mexico. Proceedings; New Mexico Conference on the Environment, Sept. 13-15, 1992. New Mexico Environ. Dept. Santa Fe, New Mexico. 1993.

Ruyle, G.B. (editor) 1997. Some methods for monitoring rangelands and other natural area vegetation. University of Arizona. Extension Report 9043. Tucson, Arizona

Stringham, T.K., W.C. Krueger, and P.L. Shaver. 2001. States, transitions and thresholds: Further refinement for rangeland applications. Agricultural Experiment Station, Oregon State University. Special report 1024.

Task Group on Unity and Terminology, Society for Range Management. 1995a. Evaluating rangeland sustainability: the evolving technology. Rangelands. 17: 85-92.

Task Group on Unity and Terminology, Society for Range Management. $1995 \mathrm{~b}$. New concepts for the assessment of rangeland condition. Journal of Range Management. 48: 271-282

Vavra, M., W.A. Laycock, and R.D. Pieper.1994. Ecological Implications of Livestock Herbivory in the West. Society for Range Management. Denver, Colorado. 